\title{
Erişkin Ailevi Akdeniz Ateşi Hastalarında Ataksız Dönemdeki Serum Amiloid A'nın Diğer İnflamatuar Belirteçlerle Korelasyonu
}

\author{
Correlation of Serum Amyloid A in the Attack-Free Period with Other Inflammatory Markers in Adult Familial
}

Mediterranean Fever Patients

${ }^{1}$ Hasan Sözel, ${ }^{2}$ Fatih Yılmaz, ${ }_{\oplus}^{1}$ Esin Avşar, ${ }_{\oplus}^{1}$ Emir Maştaoğlu, ${ }_{\oplus}^{1}$ Mustafa Serkan Alemdar,

${ }^{1}$ Feyza Bora

${ }^{1}$ Akdeniz Üniversitesi Tip Fakültesi,

İç Hastalıkları Anabilim Dalı, Antalya, Türkiye

${ }^{2}$ Antalya Atatürk Devlet Hastanesi, Nefroloji Kliniği, Antalya, Türkiye
Correspondence:

Hasan SÖZEL

Akdeniz Üniversitesi Tip Fakültesi,

İç Hastalıkları Anabilim Dalı,

Antalya, Türkiye

e-mail: dr07hasan@hotmail.com

\section{Özet}

Bu çalışmanın amacı Ailevi Akdeniz Ateşi (FMF) olan hastalarda ataksız dönemde serum amiloid A (SAA) ile klinik pratikte sık kullanılan diğer inflamatuar belirteçler arasındaki ilișkinin değerlendirilmesidir.Bu çalıșmaya FMF tanısı olan 90 hasta (38 erkek, 52 kadın) dahil edildi. FMF tanısı Tel-Hashomer kriterlerine göre konuldu. Hastalar SAA düzeyine göre iki gruba ayrıldı. Grup 1: yüksek SAA (>6.4 mg/dL), Grup 2: normal SAA ( $\leq 6.4 \mathrm{mg} / \mathrm{dL})$. Gruplarda SAA düzeyleri ile diğer inflamatuar belirteçler arasındaki korelasyon değerlendirildi. Çalıșamaya dahil edilen 90 hastanın \%56.7'sinin SAA değeri $>6.4 \mathrm{mg} / \mathrm{dL}$ ve \%43.3'ünün $\leq 6.4 \mathrm{mg} / \mathrm{dL} y d i$. Grupların serum kreatinin, tahmini glomerüler filtrasyon hızı, ürik asit, albumin, lökosit, lenfosit ve platelet sayısı ile Platelet/Lenfosit oranı (PLO) açısından anlamlı farklılık gözlenmedi. Grup 1'in ortalama fibrinojen, C-reaktif protein (CRP), eritrosit sedimentasyon hızı (ESH), Nötrofil/Lenfosit oranın (NLO) ve CRP/albümin değerleri grup 2'den istatistiksel olarak daha yüksek ve hemoglobin ortalaması ise daha düşük saptandı. Grup 1'in ortalama nötrofil ve monosit sayısı grup 2'den daha yüksekti ancak bu fark istatistiksel açıdan anlamlı değildi. SAA ile CRP arasında pozitif yönde güçlü, ESH ve CRP/albümin ile pozitif yönde orta, ve lökosit sayısı ve NLO arasında pozitif yönde zayıf bir korelasyon saptandı. CRP düzeyi FMF hastalarında ataksız dönemde SAA ile en yüksek korelasyonu göstermesi nedeniyle SAA düzeylerinin değerlendirilemediği durumlarda hastalık aktivitesi ve subklinik inflamasyonu öngörmek için kullanılabilir

Anahtar Kelimeler: Ailevi Akdeniz Ateşi; Serum Amiloid A; İnflamasyon; İnflamatuar Belirteçler

\section{Abstract}

The aim of this study is to evaluate the relationship between serum amyloid A (SAA) and other inflammatory markers frequently used in clinical practice in patients with Familial Mediterranean Fever (FMF).Ninety patients (38 males, 52 females) with a diagnosis of FMF were included in this study. FMF diagnosis was made according to Tel-Hashomer criteria. The patients were divided into two groups according to their SAA levels. Group 1:high SAA ( $>6.4 \mathrm{mg} / \mathrm{dL})$, Group 2:normal SAA ( $\leq 6.4 \mathrm{mg} / \mathrm{dL})$. The correlation between SAA levels and other inflammatory markers in the groups was evaluated.Of the 90 patients included in the study, $56.7 \%$ had SAA value $>6.4 \mathrm{mg} / \mathrm{dL}$ and $43.3 \%$ had $\leq 6.4 \mathrm{mg} / \mathrm{dL}$. There was no significant difference between the groups in terms of serum creatinine, estimated glomerular filtration rate, uric acid, albumin, leukocyte, lymphocyte and platelet counts and platelet/ lymphocyte ratio (PLR). The average fibrinogen, C-reactive protein (CRP), erythrocyte sedimentation rate (ESR), neutrophil/ lymphocyte ratio (NLR) and CRP/albumin values in group 1 were statistically higher than group 2, and the mean hemoglobin was lower. The mean neutrophil and monocyte count of group 1 was higher than group 2, but this difference was not statistically significant. There was a strong positive correlation between SAA and CRP, moderate positively with ESR and CRP/albumin, and a weak positive correlation between leukocyte count and NLR.Since the CRP level shows the highest correlation with SAA during the attack-free period in FMF patients, it can be used to predict disease activity and subclinical inflammation in cases where SAA levels cannot be evaluated.

Keywords: Familial Mediterranean Fever; Serum Amyloid A; Inflammation; Inflammatory Markers

Received 18.05.2021 Accepted 17.06.2021 Online published 17.06.2021 


\section{Giriș}

Ailevi Akdeniz ateşi (FMF), seroz membranlar, eklemler ve deride aseptik inflamasyonun eşlik ettiği tekrarlayan ve kendi kendini sınırlayan ateş ataklarıla karakterize otoinflamatuar bir hastalıktır. Bu hastalığın akut atakları kendi kendini sınırlasa da, bazı hastalarda AA tipi amiloidoz gelişir ve FMF hastalarında ciddi morbiditeden sorumlu böbrek yetmezliğine yol açabilir. Otozomal resesif geçiş gösteren FMF, Akdeniz kıyısı ülkelerinde yaygın olarak görülür. $(1,2)$. Hastalarda pirin proteinini kodlayan ve 16. kromozomun kisa kolunda bulunan MEFV (Mediterranean fever) geninin mutasyonu interlökin-1 (IL-1)' in aşırı üretimine neden olur (3). IL-1 güçlü bir inflamatuar sitokindir ve artışına plazmada Creaktif protein (CRP), eritrosit sedimentasyon h1z1 (ESH), serum amiloid A (SAA), fibrinojen seviyesinde artış gibi akut faz yanıtı ve lökositoz eşlik eder $(2,4)$.

Akut faz reaktanları, enfeksiyon, inflamasyon, neoplazi ve travma gibi tetikleyici süreçlere yanıt olarak karaciğer tarafindan sentezlenen plazma proteinleridir. Bir akut faz yanıtının ana hedefi, istilacı mikroorganizmaları veya tümör hücrelerini nötralize etmek ve doku onarımını başlatmaktır (5). Akut faz yanıtını indükleyen başlıca sitokinler, tümör nekroz faktörü $\alpha$ (TNF- $\alpha$ ), IL-1 ve interlökin-6 (IL6)'dır. $\mathrm{Bu}$ sitokinler başlıca inflamatuvar bölgelerde makrofajlar ve monositler tarafindan salgilanırlar (6). ESR, CRP, SAA ve fibrinojen gibi akut faz proteinlerinin atak dönemlerinde serum düzeyleri artar ve genellikle semptomsuz dönemlerde normale döner (7). Son çalıșmalar, FMF'de semptomsuz dönemlerde bile subklinik inflamasyonun devam edebileceğini ve hastalarda amiloidozun subklinik bir FMF periyodu sırasında da gelişebileceğini gösterdi.(8) Nötrofil/Lenfosit oranın (NLO) ve Platelet/Lenfosit oranı (PLO)'nın sistemik subklinik inflamasyonun göstergeleri olabileceği ve kardiyovasküler hastalıklar, diyabetik nefropati, maligniteler, ülseratif kolit, karaciğer sirozu ve sistemik lupus eritematozus gibi birçok hastalık durumunda kronik enflamasyonla ilişkili olabileceği bildirilmiştir (9-11). Önceki çalışmalar, FMF hastalarında NLO'nun anlamlı olarak daha yüksek olduğunu göstermiştir $(8,12)$.

FMF hastalarında CRP, SAA ve fibrinojen, S100-A12, TNF- $\alpha$, adrenomedullin, homosistein, prokalsitonin ve pentraksin-3 gibi birçok biyobelirteç, sitokin ve akut faz reaktanı çalışılmış ve hastalığın patogenezininanlaşılmasına katkıda bulunmuştur (3-5,13-16).

CRP ve albumin, enflamatuar aktivitenin ölçümü için yaygın olarak kullanılan akut faz reaktanlarıdır. CRP pozitif ve albümin ise negatif akut faz reaktanı olarak değerlendirilir. CRP/albumin oran1, CRP nin albumin düzeyine bölünmesi ile elde edilen bir skorlama sistemi olup inflamatuar durumu yalnız CRP veya albumin ölçümünden daha doğru olarak gösterir $(17,18)$.

$\mathrm{Bu}$ çalışmanın amacı, FMF hastalarında ataksız dönemde SAA ile klinik pratikte s1k kullanılan diğer inflamatuar belirteçler arasındaki ilişkinin değerlendirilmesidir.

\section{Gereç ve Yöntemler}

$\mathrm{Bu}$ çalışma Akdeniz Üniversitesi Tıp Fakültesi İç Hastalıkları polikliniğinde FMF tanısı ile takip edilen hastaların dahil edildiği retrospektif, kesitsel ve tek merkezli bir çalışma olarak tasarlandı. FMF tanısı TelHashomer tanı kriterlerine göre konuldu (19). Çalışmaya dahil edilen hastaların tümü ataksız dönemde değerlendirildi. Ataksız dönem FMF atağının sonlanmasından en az 2 hafta süre sonra, ateş ve herhangi klinik semptom ve bulgunun olmadiğ 1 evre olarak değerlendirildi. $\mathrm{Bu}$ dönemde atak öyküsü olmayan için de ateş, karın ağrısı, göğüs ağrısı, artralji, artrit, miyalji ve erizipel benzeri eritem gibi şikayetlerin son 12 saatte olmasi atak belirtisi olarak kabul edildi ve hastalar bu yönde ayrintılı sorgulanarak muayene edildi. Hastalara ait demografik veriler, tam kan sayımı, biyokimyasal tetkik ve SAA sonuçlarına hastane veri tabanı kullanılarak ulaşıldı. Hastalar SAA düzeylerine göre 2 gruba ayrıldı (grup 1: SAA düzeyi $>6,4 \mathrm{mg} / \mathrm{dL}$ ve grup 2 : SAA $\leq 6,4$ $\mathrm{mg} / \mathrm{dL})$. SAA için laboratuarımızın normal aralığını $(0-6,4 \mathrm{mg} / \mathrm{dL})$ ve literatürü $(20) \mathrm{de}$ göz önüne alarak gruplamada kesme değeri 
6,4 mg/dL olarak belirledik. Periferik kan sayımındaki nötrofil sayısını lenfosit sayısına bölerek NLO, platelet sayısını lenfosit sayısına bölerek PLO ve serum CRP değerini albumin değerine bölerek CRP/Albumin oranını elde ettik.

Tip 2 diabetes, malign hastalık, hematolojik hastal1klar, kardiyovasküler hastalıklar, romatolojik hastalıklar, obezite, aktif enfeksiyon ve FMF dışında inflamatuar hastalıklar, kolşisin ve proteinüri nedeniyle antihipertansif ilaçlar hariç uzun süreli ilaç kullanımı olan hastalar (nonsteroid antiinflamatuar ilaçlar, steroid, asetil salisilik asit, klopidogrel, immunsupresif ilaçlar), splenektomi öyküsü olanlar ve 18 yaşını doldurmamış olanlar çalışmaya dahil edilmedi. Çalışmaya dahil edilen hastaların tümü kolşisin tedavisi altındaydı ve hiçbiri IL1 blokeri kullanmiyordu. Tüm hastalar 1$1.5 \mathrm{mg} /$ gün dozunda kolşisin kullanıyordu.

\section{Etik Onay}

Çalışma için lokal etik kurul(Akdeniz Üniversitesi Tıp Fakültesi Klinik Araştırmalar Etik Kurul) onayı alındı (karar tarih/sayı:05.05.2021/327). $\mathrm{Bu}$ çalışma Helsinki Bildirgesi'nde tanımlanan etik ilkelere uygun olarak gerçekleştirildi. Çalışmamızın retrospektif doğası nedeniyle hastalardan aydınlatılmış onam formu alınmad1.

\section{Laboratuar analizi}

Tüm hastalardan 10-12 saat açlığı takiben venöz kan örnekleri alındı. Tam kan sayımı analizi için etilen daimin tetra asetik asit tüpleri kullanıldı. Tam kan sayımı parametreleri bir Sysmex XN1000 analizöründe (SysmexCorp.,Kobe Japonya) analiz edildi. Serum örneklerinde CRP düzeyi immünoturbidimetrik yöntemle, kreatinin serumda Jaffe yöntemi ile, ürik asit ürikaz enzimi ile, albümin bromokresol yeşili kullanılarak Siemens Advia 2400 biyokimya oto analizörü ile spektrofotometrik yöntemle ölçülmüştür. (Siemens Healthcare Diagnostics, Forchheim, Almanya). Tahmini Glomerüler Filtrasyon Hızı (tGFH), CKD-EPI 2009'a (Chronic Kidney Disease Epidemiologic Collaboration) dayalı olarak aşağıdaki şekilde hesaplanmıştır: tGFH $=141$ $\mathrm{x}$ dak (Scr / k, 1) ax maks (Scr / k, 1) -1,209 x0, 993 Yaş x 1,018 [Kadınlar] x 1,159 [Siyah 1rk]. - Scr $=$ serum kreatinin, $\mathrm{k}=$ kadınlar için 0,7 ve erkekler için $0,9, \mathrm{a}=$ kadınlar için 0,329 ve erkekler için $-0,411 . \min =\mathrm{Scr} / \mathrm{k}$ minimum.

Serum Amiloid A (SAA), Siemens BN ProSpec (Siemens AG, Marburg, Almanya) cihazı kullanılarak nefelometrik yöntemle çalışıldı. SAA için laboratuarımızın üst sınırı $6,4 \mathrm{mg} / \mathrm{L}$ idi. ESH, sodyum sitrat antikoagülanlı tam kan kullanılarak Westergren tekniği ile ölçüldü ve bir saatlik inkübasyondan sonra okuması yapıld1. Plazma örneklerinden fibrinojen analizi ELISAA yöntemi ile Assaypro Human Fibrinogen ELISA (Cat No: EF1040-1) kit kullanılacak Bio-Tek PowerWave XS cihazı ile yapıldı.

\section{Istatistiksel analiz}

Tanımlayıc1 istatistikler $\mathrm{n} \quad(\%)$ ve ortalama \pm standart sapma (SS) ve medyan (minimum-maksimum) değerleri ile sunuldu. Normallik varsayımı Shapiro Wilk testi ile kontrol edildi. İki grubun ölçüm değerleri arasındaki farkın analizinde normal dağılıma uymadığ1 durumda Mann-Whitney $\mathrm{U}$ testi, uyduğu durumda Student's t testi kullanıldı. SAA grupları ile cinsiyet arasındaki ilişkinin analizinde Pearson ki-kare testi, diğer sürekli değişkenler arasındaki ilişkilerin analizinde Spearman korelasyon testi kullanıldı. Tüm istatistiksel analizler IBM SPSS 23.0 paket programı (IBM Corp., Armonk, NY) ile yap1ld 1 ve $p<0,05$ istatistiksel olarak anlaml kabul edildi.

\section{Bulgular ve Analizler}

Çalışmaya dahil edilen 90 hastanın yaş ortalamas1 37,22 $\pm 11,59$ yıl, \%57,8'i kadın ve $\%$ 42,2'si erkekti. Hastaların 51'inin (\% 56,7) SAA düzeyi $>6,4 \mathrm{mg} / \mathrm{dL}$ (Grup 1) ve 39 'unun (\% 43,3) $\leq 6,4 \mathrm{mg} / \mathrm{dL}$ (Grup 2)'tü. Her iki grubun yaş ortalamaları $(\mathrm{p}=0,121)$ ve cinsiyet dağılımları $(\mathrm{p}=0,128)$ arasında istatistiksel açıdan anlamlı farklılık yoktu. Ayrıca grupların serum kreatinin $(\mathrm{p}=0,120)$, tGFH $(\mathrm{p}=0,996)$, ürik asit $(\mathrm{p}=0,413)$, albümin $(\mathrm{p}=0,856), \quad$ lökosit $\quad(\mathrm{p}=0,355), \quad$ lenfosit $(\mathrm{p}=0,231)$, platelet $(\mathrm{p}=0,746)$ ve PLO 
$(\mathrm{p}=0,316)$ değerleri açısından anlamlı fark gözlenmedi.

SAA $>6,4 \mathrm{mg} / \mathrm{dL}$ olan grup 1'in medyan fibrinojen $(p<0,001), C R P(p<0,001), E S H$

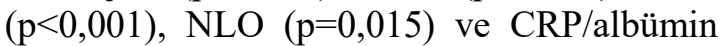
$(\mathrm{p}<0,001)$ değerleri, SAA $\leq 6,4 \mathrm{mg} / \mathrm{dL}$ olan grup 2'den istatistiksel olarak daha yüksek ve ortalama hemoglobin değeri ise $(p<0,001)$ ise daha düşüktü. Grup 1'in medyan nötrofil ve monosit değerleri daha yüksekti ancak bu fark istatistiksel açıdan anlamlı değildi (sırasıyla; $\mathrm{p}=0,084$ ve $\mathrm{p}=0,080$ ) (Tablo 1 ).

\section{Korelasyon analizi}

SAA ile yaş $(\mathrm{p}=0,429)$, kreatinin $(\mathrm{p}=0,121)$, tGFH ( $\mathrm{p}=0,584)$, ürik asit $(\mathrm{p}=0,283)$, albümin $(p=0,889)$, lenfosit $\quad(p=0,583)$, platelet $(\mathrm{p}=0,331)$ ve PLO $(\mathrm{p}=0,116)$ arasinda anlaml bir korelasyon saptanmadi. Ancak SAA ile fibrinojen $(\mathrm{r}=0,682, \quad \mathrm{p}<0,001)$ ve CRP $(\mathrm{r}=0,674, \quad \mathrm{p}<0,001)$ arasında pozitif yönde güçlü, ESH $(r=0,563, \quad p<0,001) \quad$ ve CRP/albümin $(r=0,589, p<0,001)$ ile pozitif orta düzeyde ve istatistiksel açıdan anlamlı korelasyon saptand. SAA ile hemoglobin arasında negatif yönde zayıf bir korelasyon belirlendi $(\mathrm{r}=-0,325, \quad \mathrm{p}=0,002)$. SAA ile lökosit $(r=0,308 ; p=0,003)$, nötrofil $(r=0,381$; $\mathrm{p}<0,001)$, monosit $(\mathrm{r}=0,358 ; \mathrm{p}=0,001)$ ve NLO $(\mathrm{r}=0,356 ; \mathrm{p}=0,001)$ arasinda pozitif yönde zayıf ve istatistisel açıdan anlamlı korelasyon saptand1 (Tablo 2).

\section{Tartışma ve Sonuç}

Tek merkezli, retrospektif, kesitsel bu çalışmada; FMF hastalarında ataksız dönemdeki SAA düzeyi ile klinik pratikte s1k kullanılan diğer inflamatuar belirteçler arasındaki ilişkinin değerlendirmesi ve ataksız dönemdeki subklinik inflamasyonu predikte eden ve amiloidozu öngördüren inflamatuar belirteçlerin belirlenmesi amaçlanmıştır. $\mathrm{Bu}$ çalışmada SAA ile CRP arasındaki pozitif yönde güçlü korelasyon, ESH ve CRP/Albümin arasında pozitif yönde orta düzeyde, lökosit sayısı ve NLO ile pozitif yönde zayıf bir korelasyon olduğu saptandı.

FMF'li hastalarda bir atağın karakteristik özellikleri, sıklıkla birkaç saatten 3-4 güne kadar süren ve kendini sınırlayan yüksek ateş, serözit ve cilt bulgularıdır. Sıklıkla artrit ile ilişkili olan erizipel benzeri eritem, alt ekstremitelerin distal ucunu, genellikle diz ile ayak bileği arasında ve ayak bileğine komşu proksimal ayağın sırtını tutmaya eğilimlidir $(12,21,22)$.

FMF'nin en önemli komplikasyonu kolşisin tedavisine rağmen devam eden subklinik inflamasyonun tetiklediği amiloidozdur. FMF'li hastaların önemli bir kısmında, SAA ataksız dönemlerdede yüksek kalır ve amiloidoz gelişme riskini artırır. Berkun ve arkadaşlarının çalışmasında, ataksız dönemdeki FMF hastalarının üçte birinde yüksek SAA düzeylerinin devam ettiğini, SAA düzeyi ölçümünün FMF tanısında ve kolşisin dozunun ayarlanmasında yardımcı olabileceğini belirtmişlerdir. Çünkü çalışmalarında SAA ölçümü, hastaların \% 30'unda kolşisin dozunda bir değişikliğe yol açmıştır (23).

Birçok çalışmada FMF'de çok sayıda enflamatuar belirteç incelenmiştir ve ESH, CRP, fibrinojen, SAA proteini ve lökosit sayıs1 akut faz yanıtının belirteçleri olarak kullanılmaktadır (24). Bu belirteçler atak dönemlerinde artar ve genellikle ataksiz dönemlerde normale döner fakat FMF hastalarının $\% \quad 30$ kadarında ataksız dönemlerde subklinik inflamasyon devam eder (25). Subklinik inflamasyonla birlikte artan amiloidoz riski nedeniyle, FMF hastalarında subklinik inflamasyonu belirlemek için yeni biyobelirteçler araştırılmıştır. FMF'de subklinik inflamasyon, anemi, splenomegali, azalmış kemik mineral yoğunluğu, kalp hastalığı ve özellikle ölümcül olabilen amiloidoz gibi komplikasyonların gelişme riskini artırır $(25,26)$. İnflamasayon genellikle IL-1, solübl IL-2 reseptörü, IL-6 ve TNF- $\alpha$ gibi sitokinlerin makrofajlar ve monositler tarafindan salgilanmasıyla oluşur (27). Ataksiz dönemde FMF hastalarında düzeyi artan IL-1b'ninde CRP seviyeleri ile korele olduğu ve subklinik inflamasyonu gösterebileceği belirtilmiştir (28).

NLO'nun birçok çalışmada sistemik inflamasyonun bir göstergesi olduğu gösterilmiş olup; akut koroner sendrom, kardiyovasküler hastalıklar, hipertansiyon, metabolik sendrom ve çeşitli malign durumlarla ilişkilendirilmiş ve hastalık ciddiyeti ve prognoz ve mortalite ile ilişkisi gösterilmiştir (11,29-33). 


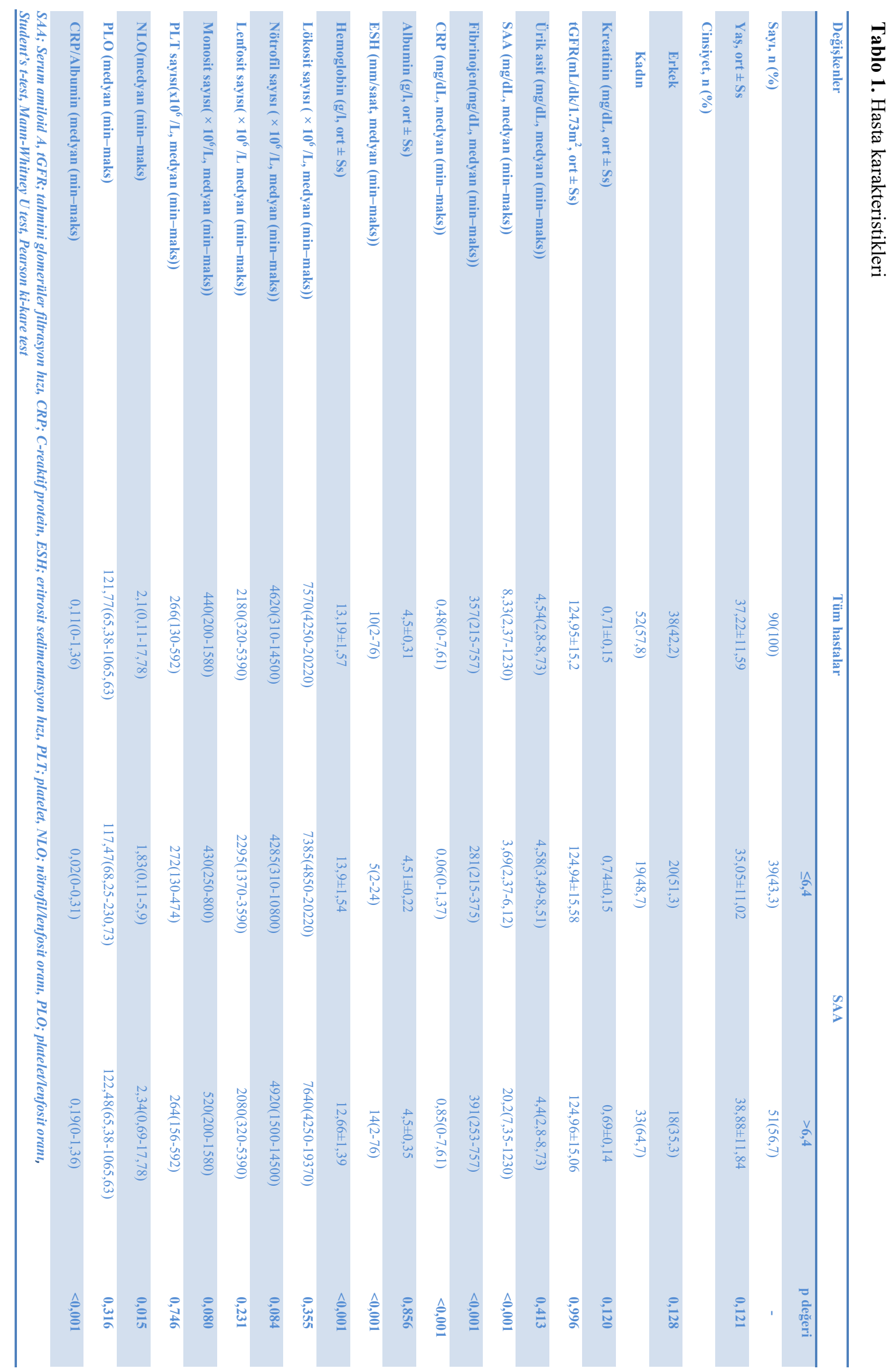


Tablo 2. SAA ile diğer parametrelerin korelasyonu

\begin{tabular}{|c|c|c|}
\hline Değişkenler & $\mathbf{r}$ & $\mathbf{p}$ \\
\hline Yaş & 0,084 & 0,429 \\
\hline Kreatinin & $-0,165$ & 0,121 \\
\hline tGFR & 0,059 & 0,584 \\
\hline Ürik asit & $-0,158$ & 0,283 \\
\hline Fibrinojen & 0,682 & $<0,001$ \\
\hline CRP & 0,674 & $<0,001$ \\
\hline Albumin & 0,018 & 0,889 \\
\hline ESH & 0,563 & $<0,001$ \\
\hline Hemoglobin & $-0,325$ & 0,002 \\
\hline Lökosit sayısı & 0,308 & 0,003 \\
\hline Nötrofil sayısı & 0,381 & $<0,001$ \\
\hline Lenfosit sayısı & $-0,059$ & 0,583 \\
\hline Monosit sayısı & 0,358 & 0,001 \\
\hline PLT sayısı & 0,104 & 0,331 \\
\hline NLO & 0,356 & 0,001 \\
\hline PLO & 0,168 & 0,116 \\
\hline CRP/Albumin & 0,589 & $<0,001$ \\
\hline \multicolumn{3}{|c|}{$\begin{array}{l}\text { SAA; Serum amiloid A, tGFR; tahmini glomerüler filtrasyon hizl, CRP; C-reaktif protein, ESH; eritrosit } \\
\text { sedimentasyon hızı, PLT; platelet, NLO; nötrofil/lenfosit oranı, PLO; platelet/lenfosit orant }\end{array}$} \\
\hline
\end{tabular}

Ülkemizde yapılan ve 168 çocuk hastanın dahil edildiği bir çalışmada, CRP ve SAA'nın FMF atakları ile iyi korelasyon gösterdiği ve SAA'nın ataksız dönemde subklinik inflamasyonu göstermede en hassas yöntem olduğu saptanmıştır. Bu çalışma atak sırasında SAA ölçümünü gerekli bulmazken ataksız dönemde inflamatuar sürecin izleminde kullanılabileceğini ortaya koymuştur (20).

Ülkemizde yapılan başka bir çalışmada 153 FMF'li çocuğun 90 sağlıklı gönüllü ile karşılaştırması yapılmış olup; NLO, PLO, ortalama trombosit hacmi (MPV) ve eritrosit dağılım genişliği (RDW)'nin FMF'li hastalarda potansiyel subklinik inflamasyon belirteçleri olduğu, semptomsuz dönemlerde de yüksek oldukları saptanmıştır. Aynı çalışmada; NLO'nin, PLO, MPV ve RDW ile karşılaştırıldığında subklinik inflamasyon için en güvenilir belirteç olduğu fakat belirteçlerin hiçbirinin proteinürik hastalarda proteinürik olmayan hastalardakinden anlamlı derecede yüksek olmadığı bulunmuştur (12).

$\mathrm{Bu}$ çalışmanın çeşitli kısıtlılıkları mevcuttur. Birincisi, tek merkezli, kısmen az sayıda hasta ile yapılması ve retrospektif özelliğidir. İkincisi FMF hastalık süreleri, aile öyküleri, MEFV gen mutasyonu sonuçlarının değerlendirilmemiş olmasıdır. Kullandıkları kolşisin dozu ve hastaların vücut kompozisyonlarına ait ayrıntılı bilgilerin edinilememiş olması ve alkol/sigara alışkanlıklarının da değerlendirilememesi çalışmanın diğer kısıtlılıklarındandır.

CRP düzeyi FMF hastalarında ataksız dönemde SAA ile en yüksek korelasyonu göstermesi nedeniyle SAA düzeylerinin değerlendirilemediği durumlarda hastalık aktivitesi ve subklinik inflamasyonu öngörmek için kullanılabilir. 


\section{KAYNAKLAR}

1. Üstebay S, Üstebay D, Y1lmaz Y. Ailevi Akdeniz Ateşi. JAREM 2015; 5: 89-93

2. Özen S, Batu ED, Demir S. Familial Mediterranean Fever: Recent Developments in Pathogenesis and New Recommendations for Management. Front Immunol. 2017;8:253.

3. Ben-Zvi I, Livneh A. Chronic inflammation in FMF: Markers, risk factors, outcomes and therapy. Nat Rev Rheumatol. 2011;7:105-112.

4. Yalçinkaya F, Çakar N, Acar B, et al. The value of the levels of acute phase reactants for the prediction of familial Mediterranean fever associated amyloidosis: A case control study. Rheumatol Int. 2007;27:517-22.

5. Fassbender K, Dempfle CE, Mielke O, et al. Proinflammatory cytokines: Indicators of infection in high-risk patients. $J$ Lab Clin Med. 1997;130:535-39.

6. Manukyan GP, Ghazaryan KA, Ktsoyan ZA, et al. Cytokine profile of Armenian patients with Familial Mediterranean fever. Clin Biochem. 2008;41:920-922.

7. Tunca M, Kirkali G, De Soytürk M, et al. Acute phase response and evolution of familial Mediterranean fever. Lancet. 1999;353:1415.

8. Ahsen A, Ulu MS, Yuksel S, et al. As a new inflammatory marker for familial mediterranean fever: Neutrophil-to-lymphocyte ratio. Inflammation. 2013;36:1357-62.

9. Sakallı H, Kal Ö. Mean platelet volume as a potential predictor of proteinuria and amyloidosis in familial Mediterranean fever. Clin Rheumatol. 2013;32:1185-90.

10. Akbas EM, Demirtas L, Ozcicek A, et al. Association of epicardial adipose tissue, neutrophil-to-lymphocyte ratio and platelet-tolymphocyte ratio with diabetic nephropathy. Int $J$ Clin Exp Med. 2014;7:1794-1801.

11. Zahorec R. Ratio of neutrophil to lymphocyte counts--rapid and simple parameter of systemic inflammation and stress in critically ill. Bratisl Lek Listy. 2001;102:5-14.

12. Özer S, Yılmaz R, Sönmezgöz E, et al. Simple markers for subclinical inflammation in patients with familial mediterranean fever. Med Sci Monit. 2015;21:298-303.

13. Yüksel S, Ekim M, Özçakar ZB, et al. The value of procalcitonin measurements in children with familial Mediterranean fever. Rheumatol Int. 2012;32:3443-47.

14. Yüksel S, Karadağli E, Evrengül H, et al. Could pentraxin-3 be a new marker for subclinical inflammation in familial Mediterranean fever? Pediatr Rheumatol. 2015, 13:P98

15. Schattner A, Lachmi M, Livneh A, et al. Tumor necrosis factor in familial Mediterranean fever. Am J Med. 1991;90:434-38.

16. Gang N, Drenth JPH, Langevitz $P$, et al. Activation of the cytokine network in familial Mediterranean fever. $J$ Rheumatol. 1999
Apr;26:890-897

17. Akkececi NS, Cetin GY, Gogebakan H, et al. The C-reactive protein/albumin ratio and complete blood count parameters as indicators of disease activity in patients with takayasu arteritis. Med Sci Monit. 2019;25:1401-09.

18. Gibson DJ, Hartery K, Doherty J, et al. CRP/Albumin Ratio: An Early Predictor of Steroid Responsiveness in Acute Severe Ulcerative Colitis. $J$ Clin Gastroenterol. 2018;52:48-52.

19. Berkun Y, Eisenstein EM. Diagnostic criteria of familial Mediterranean fever. Autoimmun Rev. 2014;13:388-90.

20. Çakan M, Karadağ ŞG, Tanatar A, et al. The Value of Serum Amyloid A Levels in Familial Mediterranean Fever to Identify Occult Inflammation During Asymptomatic Periods. $J$ Clin Rheumatol. 2021;27:1-4.

21. 21. Savic S, Dickie LJ, Wittmann M, et al. Autoinflammatory syndromes and cellular responses to stress: Pathophysiology, diagnosis and new treatment perspectives. Best Pract Res Clin Rheumatol. 2012;26:505-33.

22. Savran Y, Sari I, Leyla Kozaci D, et al. Increased levels of macrophage migration inhibitory factor in patients with familial mediterranean fever. Int $J$ Med Sci. 2013;10:836-39.

23. Berkun Y, Padeh S, Reichman B, et al. A Single Testing of Serum Amyloid A Levels as a Tool for Diagnosis and Treatment Dilemmas in Familial Mediterranean Fever. Semin Arthritis Rheum. 2007;37:182-88.

24. Guzel S, Andican G, Seven A, et al. Acute phase response and oxidative stress status in familial mediterranean fever (FMF). Mod Rheumatol. 2012;22:431-37.

25. Uslu AU, Deveci K, Korkmaz S, et al. Is neutrophil/lymphocyte ratio associated with subclinical inflammation and amyloidosis in patients with familial mediterranean fever? Biomed Res Int. 2013;2013:185317.

26. Bilginer Y, Akpolat T, Ozen S. Renal amyloidosis in children. Pediatr Nephrol. 2011;26:1215-27.

27. Baykal Y, Saglam K, Yilmaz MI, et al. Serum sIL-2r, IL-6, IL-10 and TNF-alpha level in familial Mediterranean fever patients. Clin Rheumatol. 2003;22:99-101.

28. Yildirim $\mathrm{K}$, Uzkeser $\mathrm{H}$, Keles $\mathrm{M}$, et al. Relationship between serum interleukin-1beta levels and acute phase response proteins in patients with familial Mediterranean fever. Biochem medica. 2012;22:109-13.

29. K Kiliçaslan B, Dursun H, Kaymak S, et al. The relationship between neutrophil to lymphocyte ratio and blood pressure variability in hypertensive and normotensive subjecs. Turk Kardiyol Dern Ars. 2015;43:18-24. 
30. El Shafey WEH, Emara AM, Mosa WF, et al. Predictive Value of Neutrophil-to-Lymphocyte Ratio in Outcomes of Patients with Acute Coronary syndrome. Atheroscler Suppl. 2019; 6:4

31. Farshchian N, Soleimani M, Heydarheydari S, et al. Survey of neutrophil to lymphocyte ratio as prognostic factor in colorectal cancer. Middle East Journal of Cancer, 2019;10:319-23.

32. Buyukkaya E, Karakaş MF, Karakaş E, et al. Correlation of neutrophil to lymphocyte ratio with the presence and severity of metabolic syndrome. Clin Appl Thromb Hemost. 2014;20:159-63.

33. Faria SS, Fernandes PC, Silva MJB, et al. The neutrophil-to-lymphocyte ratio: A narrative review. Ecancermedicalscience. 2016;10:702. 